\title{
GAMBARAN AKTIFITAS FISIK PADA PENDERITA HIPERTENSI
}

\author{
Description of Physical Activity in Hypertension Patient
}

\author{
Ni Kadek Yuni Lestari ${ }^{1}$, Ni Luh Gede Intan Saraswati ${ }^{2}$ \\ ${ }^{1,2}$ Departemen Keperawatan Medikal Bedah, STIKES Wira Medika Bali, Denpasar, Bali, Indonesia \\ Korespondensi : yunilestariwika@gmail.com
}

\begin{abstract}
ABSTRAK
Hipertensi merupakan penyakit tidak menular yang menjadi masalah kesehatan saat ini, prevalensi dan insiden meningkat setiap tahunnya. Aktivitas fisik merupakan salah satu faktor yang dapat diubah pada penderita hipertensi. Aktivitas yang dilakukan secara tepat dan teratur serta frekuensi dan lamanya waktu yang digunakan dengan baik dan benar dapat membantu menurunkan tekanan darah. Penderita hipertensi, menurut hasil studi pendahuluan tidak melakukan olah raga rutin namun hanya melakukan pekerjaan rumah tangga biasa. Penelitian ini merupakan penelitian deskriptif dengan rancangan crosssectional, sampel berjumlah 75 orang yang diambil dengan menggunakan teknik purposive sampling. Hasil penelitian ini menunjukkan sebagian besar penderita hipertensi memiliki aktivitas dengan kategori baik yaitu sebanyak 51 orang $(68 \%)$. Penelitian berkesimpulan bahwa penderita hipertensi memiliki aktivitas yang baik dengan jumlah responden terbanyak adalah perempuan dengan sebaran pendidikan terbanyak adalah sekolah dasar. Diharapkan perawat dapat memberikan motivasi dan edukasi yang tepat bagi penderita hipertensi untuk melakukan aktivitas fisik.
\end{abstract}

Kata kunci: aktivitas fisik, hipertensi, tekanan darah

\section{ABSTRACT}

Hypertension is a non-infectious disease which is a big problem now, prevalence and incidence increase each years. Physical activity is one factor that can be changed in people with hypertension. The right and regular activity can reduce blood pressure. Preliminary study showed that most of the patient don't exercise regularly. The purpose of this study was to describe the physical activity on hypertension patient. This research is a descriptive study with cross sectional design. This research use purposive sampling with 75 sample. The result showed that most of hypertension sample have a good activities (68\%). The study concluded that hypertension sufferers have good activities with the highest number of respondents being women with the highest distribution of education being elementary schools. It is expected that nurses can provide motivation and education for people with hypertension to carry out physical activities.

Keywords: physical activity, hypertension, blood preasure 


\section{PENDAHULUAN}

Pada tahun 2000, 51\% kematian disebabkan oleh penyakit tidak menular. Terjadinya transisi epidemiologi ini disebabkan oleh terjadinya perubahan sosial ekonomi penduduk, lingkungan dan perubahan struktur penduduk dimana masyarakatnya telah mengadopsi dan berpraktek gaya hidup tidak sehat (Rasdi et al., 2006). Salah satu penyakit tidak menular yang menjadi masalah kesehatan saat ini adalah hipertensi. Menurut World Health Organization (2007), saat ini terdapat 600 juta penderita hipertensi diseluruh dunia dan 3 juta diantaranya meninggal setiap tahunnya.

Hipertensi masih menjadi masalah utama di dunia baik di negara maju maupun negara berkembang termasuk Indonesia. Prevalensi hipertensi tertinggi ditemukan di wilayah Afrika (46\%) dari orang dewasa yang berusia $\geq 25$ tahun, sedangkan prevalensi hipertensi terendah ditemukan di Amerika (35\%) (World Health Organization, 2010). Hasil Riset Kesehatan Dasar (Riskesdas) tahun 2013 menunjukkan bahwa prevalensi hipertensi di Indonesia yang didapat melalui pengukuran tekanan darah pada umur $\geq 18$ tahun sebesar $25,8 \%$ dari penduduk Indonesia dan tertinggi di Provinsi Bangka Belitung (30,9). Prevalensi hipertensi melalui diagnosis tenaga kesehatan, tertinggi terdapat pada Provinsi Sulawesi Utara $(15,0 \%)$. Prevalensi hipertensi di Bali adalah sebesar 19,9\% dari total jumlah penduduk yaitu 840.851 jiwa. Berdasarkan dinas kesehatan Provinsi Bali tentang penyakit tidak menular (PTM), tercatat jumlah kasus hipertensi pada lansia yang terdeteksi tahun 2011 sebanyak 15.843 kasus, tahun 2012 sebanyak 23.837 kasus, tahun 2013 sebanyak 30.563 kasus, tahun 2014 sebanyak 32.897 kasus dan pada profil Kesehatan Provinsi Bali tahun 2015 berdasarkan pola 10 besar penyakit di Provinsi Bali kejadian hipertensi menduduki peringkat ke 2 dengan jumlah kasus sebanyak 89.394 kasus (Badan Penelitian dan Pengembangan Kesehatan, 2013).

Faktor risiko hipertensi terbagi dua yaitu faktor yang dapat diubah dan tidak dapat diubah. Faktor yang dapat diubah antara lain obesitas, aktivitas fisik, konsumsi garam berlebih, merokok, konsumsi alkohol dan stres. Sedangkan faktor yang tidak dapat diubah yaitu riwayat keluarga (keturunan), jenis kelamin dan umur (Suiraoka, 2012). Salah satu faktor yang dapat diubah adalah aktivitas fisik. Aktivitas fisik adalah anggota tubuh berupa otot yang bergerak dan membutuhkan energi atau suatu pergerakan yang dapat bermanfaat bagi kesehatan tubuh (Prasetyaningrum, 2014). Paruntu et al. (2015), mengatakan bahwa semakin tinggi aktivitas fisik seseorang maka semakin rendah tekanan darah atau risiko terkena penyakit hipertensi.

Aktivitas fisik yang dilakukan secara tepat dan teratur serta frekuensi dan lamanya waktu yang digunakan dengan baik dan benar dapat membantu menurunkan tekanan darah. Aktivitas fisik yang cukup dapat membantu menguatkan jantung. Jantung yang lebih kuat tentu dapat memompa lebih banyak darah meskipun hanya menggunakan sedikit usaha. Semakin ringan kerja jantung, maka semakin sedikit tekanan pada pembuluh darah arteri sehingga mengakibatkan tekanan darah menjadi turun. Kebanyakan olahraga dilakukan pada pagi hari setelah subuh karena udaranya masih bersih. Beberapa studi menunjukkan bahwa olah raga yang dilakukan secara rutin dan teratur dapat mengurangi faktor risiko terhadap penyakit jantung koroner, termasuk hipertensi (Saputri, 2010).

Berdasarkan data kunjungan penderita hipertensi di salah satu puskesmas di Ubud pada bulan September 2017 terdapat 59 orang kunjungan baru, 32 orang kunjungan lama dan 124 orang kunjungan kasus lama (lebih dari 2 kali kunjungan per bulan) (Puskesmas 1 Ubud, 2017). Hasil wawancara dengan pasien terkait aktifitas fisik yang dilakukan dari 10 pasien tidak ada yang melakukan aktifitas olahraga secara rutin, pasien hanya mengerjakan pekerjaan rumah tangga biasa. Berdasarkan uraian diatas maka peneliti melakukan penelitian untuk mengetahui gambaran aktifitas fisik pada penderita hipertensi.

\section{TUJUAN PENELITIAN}

Penelitian ini bertujuan untuk mengetahui gambaran aktivitas fisik pada penderita hipertensi 


\section{METODE PENELITIAN}

Desain

Penelitian ini merupakan penelitian deskriptif dengan pendekatan cross sectional.

\section{Populasi dan Sampel}

Populasi pada penelitian ini adalah penderita hipertensi di salah satu puskesmas di Ubud dengan jumlah sampel 75 orang yang diambil dengan menggunakan teknik purposive sampling. Adapun kriteria inklusi adalah penderita hipertensi yang berusai $15-$ 64 tahun dan bersedia menjadi responden, kriteria eksklusi pada penelitian ini adalah penderita hipertensi dengan komplikasi gagal jantung dan hipertensi heart disease

\section{Tempat dan Waktu Penelitian}

Penelitian ini dilakukan di Puskesmas 1 Ubud pada bulan November 2018

\section{Instrumen dan Prosedur Pengukuran}

Instrumen pada penelitian ini menggunakan kuisioner aktivitas fisik. Kuisioner aktivitas fisik telah dipergunakan sebelumnya pada penelitian Nur Nafidah pada tahun 2015 dengan nilai korelasi 0.3650.645 dimana nilainya lebih besar dari $r$ tabel yaitu 0.3 , yang menyatakan kuisioner telah valid dan reliabel.

\section{Analisa Data}

Data dianalisa menggunakan uji univariat untuk menentukan distribusi frekuensi dari variabel.

\section{HASIL PENELITIAN}

Hasil penelitian gambaran aktivitas fisik pada penderita hipertensi dapat dilihat pada tabel 1 .

Tabel 1

Aktifitas Fisik Penderita Hipertensi ( $\mathrm{n}=75)$

\begin{tabular}{ccc}
\hline Aktivitas & Frekuensi & Persentase \\
\hline Baik & 51 & $68 \%$ \\
\hline Cukup & 24 & $32 \%$ \\
\hline Kurang & 0 & 0 \\
\hline Total & 75 & $100 \%$ \\
\hline
\end{tabular}

Tabel 1 menggambarkan sebagian besar penderita hipertensi memiliki aktivitas dengan kategori baik yaitu sebanyak 51 orang (68\%).

\section{Tabel 2}

Hasil Tabulasi Silang Aktifitas Fisik dan Jenis Kelamin Penderita Hipertensi $(n=75)$

\begin{tabular}{|c|c|c|c|}
\hline \multirow{2}{*}{$\begin{array}{c}\text { Aktivitas } \\
\text { fisik }\end{array}$} & \multicolumn{2}{|c|}{ Jenis Kelamin } & Total \\
\hline & Laki-laki & Perempuan & \\
\hline Baik & 18 & 33 & 51 \\
\hline Cukup & 16 & 8 & 24 \\
\hline Kurang & 0 & 0 & 0 \\
\hline Total & 34 & 41 & 75 \\
\hline
\end{tabular}

sebagian besar jenis kelamin yang memiliki aktivitas cukup adalah laki laki yaitu sebanyak 16 orang, sedangkan sebagian besar jenis kelamin yang memiliki aktivitas fisik baik adalah perempuan yaitu sebanyak 33 orang. Hasil penelitian didapatkan hasil bahwa penderita hipertensi dengan aktivitas fisik baik sebanyak 51 responden (68\%) dan aktivitas cukup sebanyak 24 responden $(32 \%)$.

\section{PEMBAHASAN}

Hasil penelitian ini sejalan dengan penelitian Putritsani \& Kusuma (2018), tentang gambaran aktifitas fisik pada penderita hipertensi di Puskesmas Kedungmundu Kota Semarang, dimana sebagian besar responden memiliki tingkat aktivitas fisik sedang (43.3\%). Aktivitas fisik merupakan faktor risiko kejadian hipertensi pada lansia, namun tetap diharapkan untuk rutin melakukan aktivitas fisik karena apabila dilakukan secara tepat dan teratur serta frekuensi dan lamanya waktu yang digunakan dengan baik dan benar maka dapat menurunkan tekanan darah. Olahraga secara teratur paling sedikit 30 menit/hari minimal tiga hari per minggu ideal untuk sebagian besar pasien hipertensi (Saputri, 2010). Faktor yang mempengaruhi aktivitas fisik antara lain tingkat perkembangan tubuh, kesehatan fisik, keadaan nutrisi, emosi, kelemahan 
neuromuskuler dan skeletal dan pekerjaan (Tarwoto, 2010).

Aktivitas fisik adalah pergerakan anggota tubuh yang menyebabkan pengeluaran tenaga yang sangat penting bagi pemeliharaan kesehatan fisik dan mental, serta mempertahankan kualitas hidup agar tetap sehat dan bugar sepanjang hari. Aktivitas fisik ringan secara independen mempengaruhi terjadinya hipertensi. Semakin ringan aktivitas fisik semakin meningkatkan risiko terjadinya hipertensi. Lansia yang tidak melakukan aktivitas fisik akan meningkatkan risiko kejadian hipertensi sistolik terisolasi sebesar 2,33 kali lebih besar dibandingkan dengan lansia yang melakukan aktivitas fisik dan bermakna.

Berdasarkan hasil penelitian sebagian besar lansia yang mengalami hipertensi melakukan aktivitas fisik ringan. Responden yang melakukan aktivitas fisik dengan baik karena merupakan aktivitas rutin yang dilakukan setiap hari seperti duduk, berjalan-jalan di kamar dan mengikuti senam. Pada masa lansia mulai terjadi penurunan hormon estrogen sehingga berdampak pada kondisi tubuh \& juga mentalnya. Akibatnya akan mengganggu aktivitas pada lansia. Karena perubahan tersebut mengakibatkan kegiatan fisik lansia menjadi kurang menyenangkan atau cepat merasa lelah jika melakukan aktivitas. Kelelahan dapat menjadi respon normal terhadap aktivitas fisik dan mental, penyebab kelelahan yang biasa dialami setiap orang diantaranya adalah kurang tidur, stres dan cemas. Aktivitas fisik seperti olahraga diharapkan untuk rutin melakukan aktivitas fisik karena apabila dilakukan secara tepat dan teratur serta frekuensi dan lamanya waktu yang digunakan dengan baik dan benar maka dapat menurunkan tekanan darah.

Sesuai dengan teori Suryadi (2017) salah satu fenomena lansia setelah mereka memasuki masa pensiun atau usia yang dianggap sudah tua (60 tahun) oleh sebagian masyarakat adalah menarik diri dari segala bentuk aktivitas. Masyarakat cenderung dengan pemikiran negatif yang belum tentu kebenarannya (stereotype) oleh masyarakat seperti lansia sudah saatnya pensiun dari aktivitas; lansia itu selalu sakit-sakitan.
Akhirnya banyak lansia yang menganggap dirinya sudah harus masuk dan diam saja di rumah.

Hasil penelitian didapatkan data bahwa jenis aktivitas fisik yang dilakukan penderita hipertensi khususnya yang memasuki masa lanjut usia seperti melakukan aktivitas duduk, berjalan-jalan di dalam kamar atau di luar kamar, menyapu di sekitarnya, mengepel lantai, mencuci piring atau pakaian, mengikuti senam, melakukan ibadah atau sembahyang, membawa makanan dari dapur ke kamar, berkebun atau bertani dan menyiram tanaman. Sebagian besar penderita hipertensi di salah satu Puskesmas di Ubud memiliki tingkat aktifitas fisik yang baik. Lansia yang dapat mempertahankan aktivitas pada usia dewasa pertengahan serta lansia yang masih aktif dan dapat melakukan aktivitas fisik akan memberikan kontribusi paling besar terhadap masa tua yang sukses. Successful aging atau keberhasilan usia lanjut dapat dilihat melalui aktivitas kesehariannya dan akan terus menunjukkan peningkatan apabila lansia melakukan peningkatan mutu dalam aktivitas keseharian yang dilakukan oleh para lansia, terutama dalam hal melakukan pekerjaan berat yang membutuhkan tenaga lebih banyak (Maskhuri \& Kusumaningtyas, 2017).

\section{KESIMPULAN \\ Implikasi}

Hipertensi merupakan salah satu penyakit non infeksius yang telah menjadi masalah di seluruh dunia sehingga dengan adanya penelitian ini dapat memberikan manfaat sebagai data bagi para tenaga kesehatan khususnya perawat untuk lebih menggalakkan program terkait pencegahan komplikasi terkait hipertensi, pemberian motivasi dan edukasi bagi penderita hipertensi dalam mengikuti kegiatankegiatan prolanis.

\section{Keterbatasan}

Penelitian ini hanya bersifat dekriptif dan perlu dikembangkan menjadi penelitianpenelitian dengan lebih banyak variable dengan menggunakan rancangan yang bersifat kausal, selain itu penelitian perlu 
dilakukan pada wilayah yang meliputi seluruh puskesmas di Bali.

\section{DAFTAR PUSTAKA}

Badan Penelitian dan Pengembangan Kesehatan. (2013). Riset Kesehatan Dasar (RISKESDAS) 2013. In Laporan Nasional 2013 (pp. 1-384). Jakarta: Kementerian Kesehatan Republik Indonesia. https://doi.org/1 Desember 2013

Maskhuri, S. A., \& Kusumaningtyas, R. (2017). Komunikasi Interpersonal Perawat Dengan Lansia. Universitas Muhammadiyah Surakarta. Retrieved from http://eprints.ums.ac.id/57170/

Paruntu, O. L., Fisik, H. A., Gizi, S., Hipertensi, D. A. N., Paruntu, O. L., Rumagit, F. A., ... Tomohon, D. K. (2015). Hubungan Aktivitas Fisik, Status Gizi dan Hipertensi Pada Pegawai Di Wilayah Kecamatan Tomohon Utara. GIZIDO, 7(1), 1-6.

Prasetyaningrum, Y. I. (2014). Hipertensi Bukan untuk Ditakuti. (D. Ari \& Y. Tetty, Eds.). Jakarta: FMedia. Retrieved from https://books.google. co.id/

Puskesmas 1 Ubud. (2017). Laporan Tahunan Puskesmas 1 Ubud. Gianyar.

Putritsani, R., \& Kusuma, H. (2018). Gambaran Aktivitas Fisik Pada Penderita Hipertensi Di Wilayah Kerja Puskesmas Kedungmundu Kota Semarang. Universitas Diponegoro. Retrieved from http://eprints.undip. ac.id/63242/

Rasdi, N., et.al. (2006). Analisis Faktor Resiko Kejadian Hipertensi Pada Dewasa Muda Di Unit Rawat Jalan RSU Labuang Baji Makasar. Kemas, 2(1), 303-308.

Saputri, D. E. (2010). Hubungan Stres Dengan Hipertensi Pada Penduduk Di Indonesia Tahun 2007 (Analisa Data Riskesdas 2007). Universitas Indonesia.

Suiraoka. (2012). Penyakit Degeneratif. Yogyakarta: Nuha Medika.

Suryadi. (2017). Aktivitas Lansia. Ponorogo: Wade Group.

Tarwoto, W. (2010). Kebutuhan Dasar
Manusia dan Proses Keperawatan. Jakarta: Salemba Medika.

World Health Organization. (2007). Prevention of Cardiovascular Disease (Guidelines for assessment and management of cardiovascular risk). Geneva.

World Health Organization. (2010). The Definition of Hypertension. Geneva. Retrieved from https://www.who .int/data/gho 